\title{
The effect of subclinical ketosis on activity at estrus and reproductive performance in dairy cattle
}

\author{
Andrew J. Rutherford, ${ }^{*}$ Georgios Oikonomou, ${ }^{*}{ }^{1}$ and Robert F. Smith* \\ "Livestock Health and Welfare, School of Veterinary Science, University of Liverpool, Liverpool, CH64 7TE, United Kingdom \\ †Department of Epidemiology and Population Health, Institute of Infection and Global Health, University of Liverpool, Liverpool, \\ CH64 7TE, United Kingdom
}

\section{ABSTRACT}

Our aims were to investigate the influence of subclinical ketosis (SCK) on physical activity at estrus using a neck accelerometer device and on future reproductive performance. Two hundred three Holstein-Friesian cows were studied on 3 dairy farms in Northwest England between September 2013 and March 2014. Seventeen percent (35 of 203) of the enrolled cows were affected with SCK between 7 and $21 \mathrm{~d}$ in milk, defined as a blood $\beta$-hydroxybutyrate concentration of 1.2 to $2.9 \mathrm{mmol} / \mathrm{L}$. Time to event analyses and multivariable regression analyses were used to assess the effect of SCK on reproductive performance and activity at estrus. The SCK cows exhibited a lower peak activity (measured as the number of standard deviations above mean activity) and shorter duration in activity clusters associated with first estrus and first insemination postpartum, compared with non-SCK cows. Peak activity and cluster duration associated with the insemination that led to a pregnancy were not different between SCK and non-SCK cows. Calving to first estrus, calving to first insemination, and calving to pregnancy intervals were prolonged in SCK cows. First insemination was 4.3 times $(95 \%$ confidence interval $=1.6$ to 15.0$)$ less likely to be successful in SCK cows compared with nonSCK cows. Adjusted mean number of inseminations per pregnancy was 2.8 for SCK cows and 2.0 for non-SCK cows. The current study confirms the long-lasting effects of SCK on reproductive efficiency. Furthermore, it is indicated that physical activity around estrus is reduced by SCK in early lactation, but this negative effect appears to diminish as cows progress through lactation.

Key words: subclinical ketosis, $\beta$-hydroxybutyrate, estrus activity

Received July 22, 2015.

Accepted February 8, 2016.

${ }^{1}$ Corresponding author: goikon@liv.ac.uk

\section{INTRODUCTION}

In early lactation, all dairy cattle undergo a period of negative energy balance (NEB), metabolic stress, and a degree of body condition loss due to mobilization of body reserves in response to increased energy requirements for lactogenesis (Drackley, 1999; Herdt, 2000). A delayed increase in DMI, genetic selection for greater milk production, and inappropriate diets can further augment the duration and magnitude of NEB (van Arendonk et al., 1991; Dechow et al., 2003; Ospina et al., 2010). This can potentially lead to development of ketosis, elevated levels of ketone bodies, such as acetone, acetoacetate, and BHB, found in body fluids (Enjalbert et al., 2001; Geishauser et al., 2001). Subclinical ketosis (SCK) is defined as high blood concentrations of ketone bodies without the signs that accompany clinical ketosis (Andersson, 1988).

More than $90 \%$ of SCK cases occur during the first and second months postpartum, with the former containing the peak prevalence (Duffield et al., 1997; Suthar et al., 2013). In the first 65 DIM, the prevalence of SCK ranged from 7 to $34 \%$, with considerable between herd and study variation (Duffield et al., 2009; McArt et al., 2012; Suthar et al., 2013). The gold standard diagnostic test for SCK is the measurement of BHB in serum, plasma, or whole blood, as it is more stable than acetone or acetoacetate (Duffield et al., 1998; Oetzel, 2004). It is considered normal to have increased ketone bodies due to the natural metabolic response to the increase in energy demand in early lactation. However, postpartum blood concentrations of BHB above certain cut-off levels have been associated with poor reproductive performance, reduced milk yield, and increased risk of displaced abomasum (McArt et al., 2013). A blood BHB of 1.2 to $2.9 \mathrm{mmol} / \mathrm{L}$ has been described to identify cows with $\mathrm{SCK}$ and values $\geq 3.0 \mathrm{mmol} / \mathrm{L}$ indicate clinical ketosis (Oetzel, 2004; Duffield et al., 2009).

The effect of NEB during early lactation on later reproductive performance is well documented, acting via disruption of the hypothalamus-pituitary-ovary axis (Butler, 2003). Both the duration and magnitude of NEB have been associated with increased concentra- 
tions of growth hormone and decreased concentrations of insulin and IGF; directly reducing follicular competence and its response to circulating gonadotrophins (Lucy, 2001; Butler, 2003). Furthermore, NEB has been linked with delaying and reducing the magnitude of the LH surge, resulting in delayed resumption of luteal activity, increased incidence of cystic ovarian disease, and a lower probability of pregnancy to first insemination (Opsomer et al., 2000; Ospina et al., 2010; McArt et al., 2012).

In the modern high-yielding dairy cow, estrus detection and thus submission rates to insemination have decreased (Dobson et al., 2007). This is attributed to shorter periods of estrus with fewer behavioral signs exhibited together with a lower serum estradiol concentration, the major stimulus for estrus behavior (Lopez et al., 2004). Lameness, high SCC, low BCS, and high milk production can have detrimental effects on dairy cow fertility, reducing the release of $\mathrm{GnRH}$, thus resulting in reduced LH pulsatility, which depresses estradiol production and disrupts estrus behavior (Dobson et al., 2007). However, the negative effect of NEB on estrus expression has not been investigated; it has been postulated that NEB leads to reduced pre-ovulatory estradiol concentrations, resulting in poor estrus expression (Lucy, 2000).

Increased activity has been shown to be associated with periods of estrus; activity monitors (accelerometers or pedometers) have recorded increases from 200 to $400 \%$ in animals exhibiting primary and secondary signs of estrus (Nebel et al., 2000; Firk et al., 2002). Many studies have identified that activity monitors with or without visual observation can accurately identify cows in estrus (Holman et al., 2011; Neves et al., 2012; Fricke et al., 2014). The main objective of the present study was to compare the physical activity at estrus, measured by neck accelerometer devices (Heatime, SCR, Netanya, Israel), of cows with SCK in early lactation to that of cows not affected with SCK in early lactation. A secondary objective was to compare the reproductive performance of SCK cows to that of non-SCK cows.

\section{MATERIALS AND METHODS}

The study was performed under UK Animals (Scientific Procedures) Act 1986 project license (PIL 40/10876) for work on living animals and with the approval of the University of Liverpool Ethical Review Process. Assuming a mean calving to conception interval of $90 \mathrm{~d}$, a 35-d SD, and a SCK prevalence of $20 \%$, it was estimated that 185 cows would be adequate to detect a 20-d difference between SCK and non-SCK cows using an $\alpha$ of 0.05 and $80 \%$ power.
A prospective cohort study design and 203 HolsteinFriesian cows on 3 commercial dairy farms in northwest England were used. The study was conducted between September 2013 and March 2014. Herd size ranged from 190 to 350 cows with a mean 305-d milk yield of $9,786 \mathrm{~kg}$ (ranging from 9,846 to $10,136 \mathrm{~kg}$ ). All 3 farms operated an all-year-round calving pattern, and cows were milked twice daily. The early lactation cows that were eligible for the study were housed in free stalls throughout the year and fed a partial mixed ration supplemented with in-parlor concentrate feeding according to milk yield.

Cows ranging from first to eighth parity were enrolled into the study. For analysis purposes, cows were subsequently categorized in 3 parity groups: group 1 for primiparous animals, group 2 for second-parity animals, and group 3 for animals in their third or greater parity. Eligible cows were between 7 and 21 DIM with no previous episodes of lameness or mastitis since calving. Each farm was visited weekly whereby the cows' reproductive tracts were examined at the time of enrollment by palpation per vagina, and rectal ultrasound using a $7.5-\mathrm{MHz}$ linear array rectal probe (Easiscan $3, \mathrm{BCF}$ Technology, Bellshill, UK). The incidence of metritis and vulval discharge (VLD) as described according to Sheldon et al. (2006) and the presence and size of any ovarian structures were recorded. The reproductive tracts of all the cows were again examined at 21 to 28 DIM with the addition of ovarian structures being noted and measured.

At enrollment, a single blood sample was collected by coccygeal venipuncture into lithium heparin tubes, and immediately analyzed for BHB using the Optium Xceed BHBA meter (Abbott, Maidenhead, UK) according to the manufacturer's instructions. This meter has been validated for BHB measurements in bovine blood samples (Iwersen et al., 2009). Cows that were found to have blood BHB concentration from 1.2 to 2.9 $\mathrm{mmol} / \mathrm{L}$ were considered to have SCK (Oetzel, 2004). These cows were not treated and farmers were blinded to our measurements. However, cows found to have blood BHB concentration $>3 \mathrm{mmol} / \mathrm{L}$ were considered to be clinically affected, were treated per farm protocol, and were not enrolled in our study.

Each cow was fitted with a neck accelerometer collar at enrollment. Mean individual cow activity was monitored and downloaded via infrared telemetry located in the milking parlor in 2-h blocks to the Heatime control box. The mean activity of an individual cow was generated from the equivalent 2-hourly block from the previous $8 \mathrm{~d}$. The intervention level to indicate an activity cluster (potential estrus episode) was set at the manufacturer's default setting of a value $\geq 5$ standard deviations above the mean weighted activity for a 
minimum of 2 consecutive $2 \mathrm{~h}$ blocks. Peak activity was measured in standard deviations above the mean activity, but a maximum of 15 standard deviations could be recorded by the software version supplied (PC Heatime Monitor v4.51). The duration of each activity cluster was measured in hours and defined as the time interval between the first and last 2-h period of increased activity above 5 standard deviations.

Artificial insemination was conducted twice daily (a.m. and p.m.) by each farm's trained inseminator, with cows receiving a single AI using nonsexed semen from Holstein-Friesian sires. Each farm used their standard criteria for estrus identification with detection being primarily observational supplemented with detection of increased activity. No farmer would inseminate cows solely on Heatime data. Each farm's inseminator was given a data capture form for each enrolled cow to record primary (standing to be mounted) and secondary (mounting other cows, restlessness, mucus discharge, sniffing and licking the vulva of other cows) signs of estrus behavior and any activity cluster within $24 \mathrm{~h}$. Production and fertility data as well as the incidence of retained fetal membranes (RFM), information regarding dystocia, and information regarding sires' predicted transmitting ability for milk yield were collected via The Cattle Information Services milk recording organization (Rickmansworth, UK). Heatime data were downloaded at monthly intervals from the control box using the accompanying software to a personal computer. All cows were monitored until either removed from the herd (culled or died), confirmed pregnant or the end of the study period had been surpassed, whichever occurred first. Pregnancy diagnosis occurred from 4 wk post-AI using transrectal ultrasonography with a positive diagnosis based on the presence of an embryo or fetus surrounded by clear amniotic fluid with a detectable heartbeat.

\section{Statistical Analysis}

Data were analyzed using JMP Pro 11 (SAS Institute Inc., Cary, NC). Mixed effects multivariable regression models were built to assess the association between SCK and each activity cluster duration or peak activity for the first estrus, estrus that led to the first insemination, and estrus that led to pregnancy. Activity cluster duration and SD above mean peak activity were continuous outcome variables. The following independent variables were entered into the model as fixed effects: diagnosis of SCK at 7 to 21 DIM (0/1), a categorical variable characterizing each evaluated event $(1=$ first observed estrus, 2 = estrus that led to the first insemination, 3 $=$ estrus that led to pregnancy), parity (groups 1 to 3 ), sire predicted transmitting ability for milk yield, dysto- cia, RFM, metritis, and VLD. The interaction between SCK and each event $(1=$ first observed estrus, $2=$ estrus that led to the first insemination, $3=$ estrus that led to pregnancy) was also offered in the models. Additionally, the random effect of the cow nested within farm was fitted in the models. Variables were removed from the models manually in a stepwise manner, and only variables with $P<0.05$ were kept in the final model. The Akaike's information criterion was used to evaluate models' goodness of fit.

Cox proportional hazard analysis with right censoring was originally used to explore the effect of SCK on the intervals from calving to first observed estrus, from calving to first insemination and from calving to pregnancy. Potential confounding variables offered to these models were parity, RFM, farm, dystocia, metritis, and VLD. None of these confounding variables were found to be important $(P>0.05)$ with the exception of an effect of metritis on the interval from calving to pregnancy. However, removing metritis from the model did not change the hazard ratio estimates for SCK. In addition, Cox proportional hazard analysis exploring the effect of SCK on the interval from calving to pregnancy suggested a significant SCK with parity interaction. Therefore simpler, Kaplan-Meier time to event analyses with right censoring were eventually used to explore the effect of SCK on the intervals from calving to first observed estrus, from calving to first insemination and from calving to pregnancy. Analysis for the effect of SCK on the interval from calving to pregnancy was conducted for each different parity group separately.

Multivariable logistic regression models were built to assess the association between SCK and pregnancy risk at the first $\mathrm{AI}(0=$ unsuccessful, $1=$ successful $)$, presence or absence of VLD, or the presence or absence of a CL at 21 to 28 DIM. A multivariable linear regression model was built to assess the association between SCK and number of inseminations per pregnancy. The following independent variables were offered to all these models: diagnosis of SCK (0/1), farm, parity, dystocia, RFM, and metritis. Presence or absence of VLD was offered to all the models except for the model that had VLD as an outcome variable. Variables were removed from the models manually in a stepwise manner, and only variables with $P<0.05$ were kept in the final models. The Akaike's information criterion was used to evaluate models' goodness of fit.

\section{RESULTS}

Descriptive characteristics of enrolled cows and SCK prevalence by herd are presented in Table 1. Twelve cows were removed from their herd within the first $28 \mathrm{~d}$ DIM and were only included in the time to event analy- 
Table 1. Descriptive statistics of 305-d milk yield and prevalence of subclinical ketosis (SCK) by herd ${ }^{1}$

\begin{tabular}{|c|c|c|c|c|c|c|}
\hline \multirow[b]{2}{*}{ Herd } & \multirow[b]{2}{*}{ Milk yield \pm SD } & \multirow[b]{2}{*}{$\mathrm{n}$} & \multicolumn{3}{|c|}{ Parity group (n) } & \multirow{2}{*}{$\begin{array}{c}\text { SCK } \\
\text { prevalence }(\%)\end{array}$} \\
\hline & & & 1 & 2 & 3 & \\
\hline 1 & $9,733 \pm 1,626$ & 56 & 20 & 12 & 24 & 20 \\
\hline 2 & $10,106 \pm 1,079$ & 74 & 25 & 12 & 37 & 11 \\
\hline 3 & $10,518 \pm 1,680$ & 73 & 23 & 14 & 36 & 22 \\
\hline Total & & 203 & 68 & 38 & 97 & \\
\hline Overall mean & $10,128 \pm 1,478$ & & & & & 17 \\
\hline
\end{tabular}

${ }^{1}$ Number of cows in each different parity group (group 1 for primiparous animals, group 2 for second-parity animals, and group 3 for animals in their third or greater parity) by herd is also provided. Milk yield = mean 305-d milk yield $(\mathrm{kg})$.

ses. Reasons for early exiting were death (3), displaced abomasum (4), mastitis (4), or unknown (1). A further 11 cows were removed from their herd later in the study (greater than 28 d DIM) due to nonreproductive reasons of mastitis (4), lameness (5), displaced abomasum (1), or death (1); their data were included in the time to event analyses, and in the estrus behavior analysis until the time of their exit.

Overall, subclinically ketotic cows, compared with non-SCK cows, were active for shorter periods of time $(\mathrm{LSM} \pm \mathrm{SE}$ of $10.7 \pm 0.7$ and $12.5 \pm 0.3 \mathrm{~h}$, respectively, $P=0.02$ ) and had a lower peak activity at estrus $(\mathrm{LSM} \pm \mathrm{SE}$ of $9.3 \pm 0.5$ and $14.3 \pm 0.2 \mathrm{SD}$ increase at mean activity, respectively, $P<0.001)$. The interaction between SCK and each different event (first observed estrus, estrus that led to the first insemination, estrus that led to pregnancy) suggested that SCK cows exhibited lower peak activity and shorter duration in activity clusters associated with first observed estrus compared with non-SCK cows. Additionally, SCK cows exhibited lower peak activity in activity clusters associated with the estrus that led to the first insemination compared with non-SCK cows. The least squares means for cluster duration and peak activity in non-SCK and SCK cows associated with first observed estrus, estrus leading to first insemination, and estrus leading to pregnancy are presented in Figure 1.

Kaplan-Meier time to event analysis with right censoring showed that cows with SCK identified at 7 to 21 DIM had a delayed interval from calving to first observed estrus compared with non-SCK cows (Figure 2). In addition, the calving to first insemination interval and the calving to pregnancy interval were prolonged in SCK cows (Figures 3 and 4A, respectively). KaplanMeier time to event analysis exploring the effect of SCK on the interval from calving to pregnancy was also conducted for each different parity group separately. Subclinical ketosis did not have an effect on the interval from calving to pregnancy in primiparous cows (median of 98 and 108 for non-SCK cows and SCK cows, respectively, $P=0.69)$. However, the interval from calving to
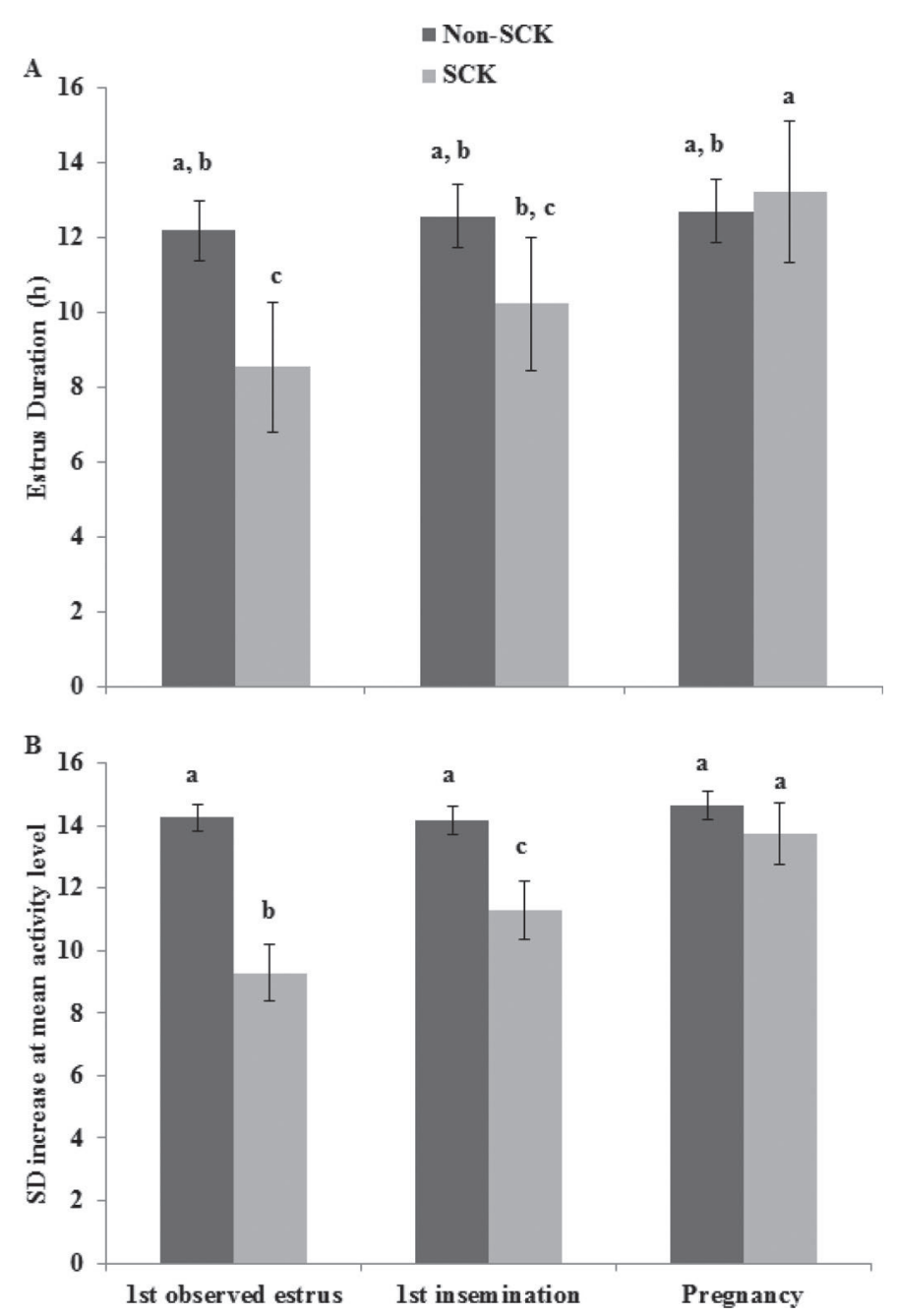

Figure 1. Least squares means $( \pm 95 \%$ CI $)$ for 191 cows from 3 herds are reported for increased activity cluster duration (A) and peak activity increase (B) in subclinically ketotic (SCK, $\mathrm{n}=34$ ) and non-SCK $(n=157)$ cows associated with first recorded estrus, estrus leading to first insemination, and estrus leading to pregnancy. Least squares means not connected by the same letter $(\mathrm{a}-\mathrm{c})$ are significantly $(P<0.05)$ different (Tukey honestly significant difference test). One hundred ninety-one cows from 3 different herds were included in this analysis. 


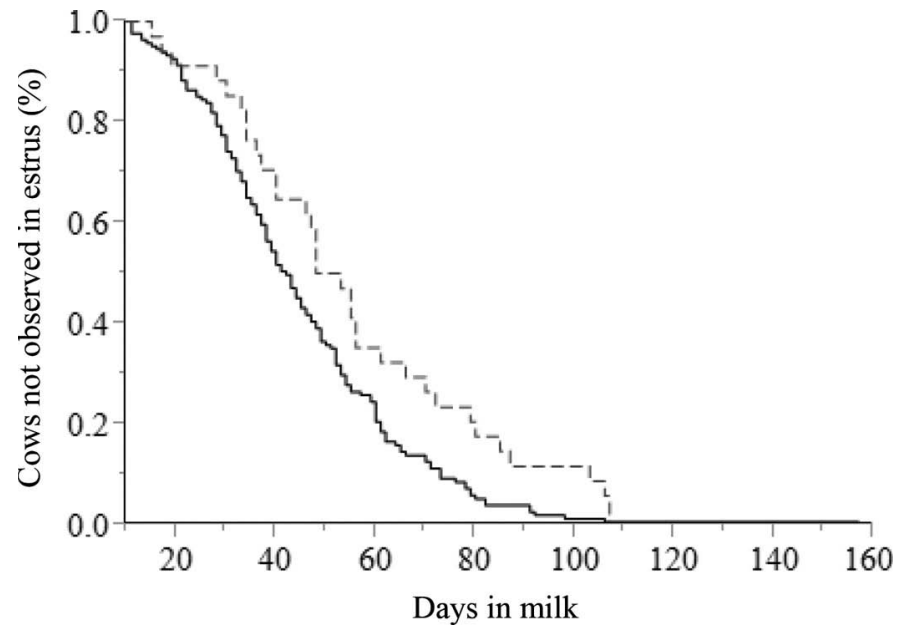

Figure 2. Kaplan-Meier time to event plot demonstrating the effect of subclinical ketosis (SCK) on the number of days from calving to first observed estrus event for 203 cows from 3 herds. Median time to event was 51 and $42 \mathrm{~d}$ for SCK (dashed line, $\mathrm{n}=35$ ) and non-SCK (solid line, $\mathrm{n}=168)$ cows, respectively $(P=0.01)$.

pregnancy was prolonged in SCK second parity cows, and in SCK cows in their third or greater parity (Figures $4 \mathrm{~B}$ and $4 \mathrm{C}$, respectively).

By the end of March 2014, 180 of the animals (88\% of the non-SCK cows and $91 \%$ of the SCK cows) had been inseminated and 168 were diagnosed as pregnant ( $95 \%$ of non-SCK cows and $84 \%$ of SCK cows that were inseminated). First insemination was 4.3 times (95\% $\mathrm{CI}=1.6$ to 15.0$)$ less likely to be successful in SCK

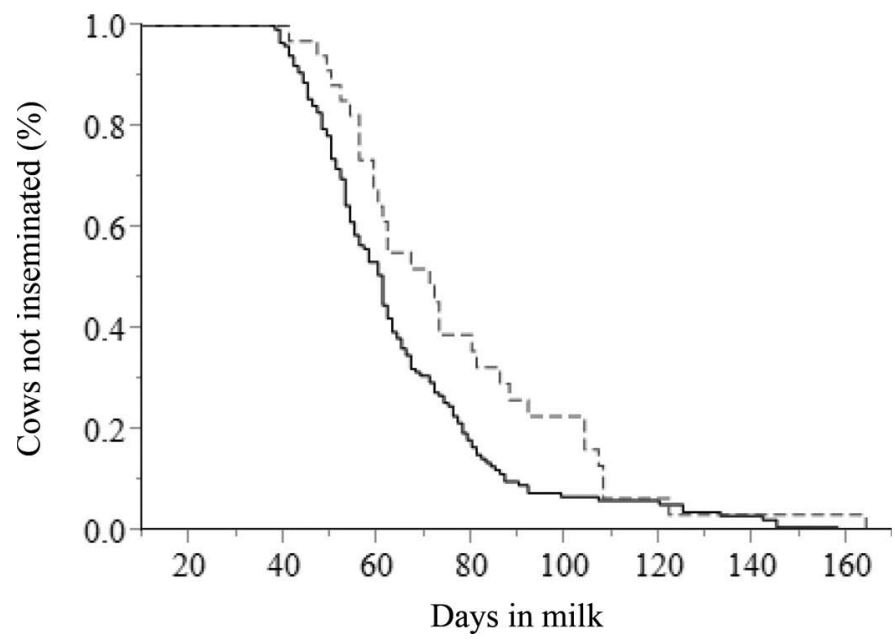

Figure 3. Kaplan-Meier time to event plot demonstrating the effect of subclinical ketosis (SCK) on the number of days from calving to first insemination for 203 cows from 3 herds. Median time to event was 71 and $61 \mathrm{~d}$ for SCK (dashed line, $\mathrm{n}=35$ ) and non-SCK (solid line, $\mathrm{n}$ $=168)$ cows, respectively $(P=0.02)$.
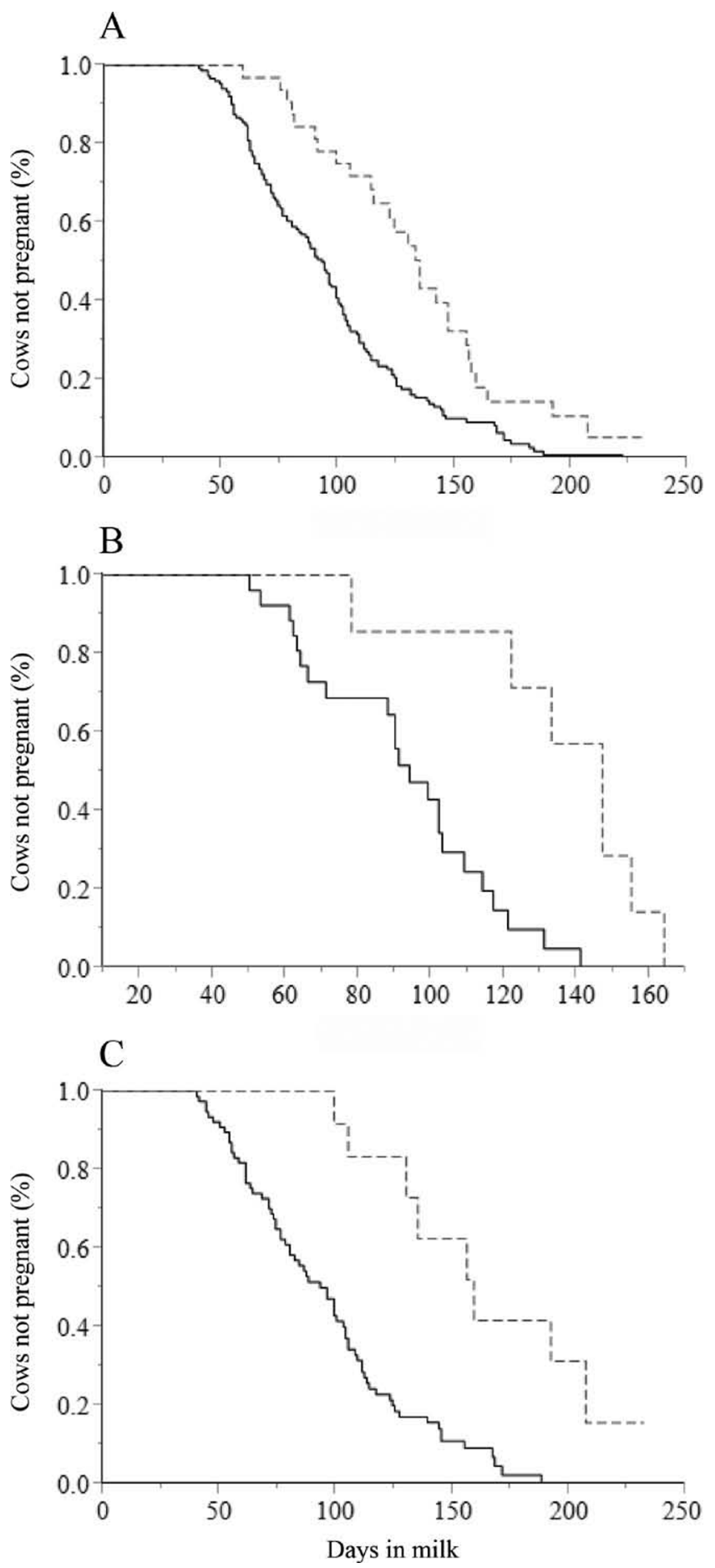

Figure 4. Kaplan-Meier time to event plots demonstrating the effect of subclinical ketosis (SCK) on the number of days from calving to pregnancy for $(\mathrm{A})$ all studied cows $(\mathrm{n}=203)$ from 3 herds, (B) 38 second-parity cows from 3 herds, and (C) 97 third and greater parity cows from 3 herds. Dashed lines represent SCK cows, and solid lines represent non-SCK cows. Median time to event was (A) 93 and 135 $\mathrm{d}$ for non-SCK and SCK cows, respectively $(P<0.001)$, (B) 94 and 147 for non-SCK second parity cows and SCK second-parity cows, respectively $(P<0.001)$, and $(\mathrm{C}) 96$ and $159 \mathrm{~d}$ for non-SCK third and greater parity cows and SCK third and greater parity cows, respectively $(P<0.001)$. 
cows compared with non-SCK cows. None of the other variables examined were found to be associated with pregnancy risk at first insemination.

Adjusted mean number of inseminations per pregnancy $( \pm \mathrm{SE})$ was $2.8 \pm 0.3$ for SCK cows and $2.0 \pm 0.1$ for cows not affected with SCK $(P<0.05)$. Dystocia was found to affect number of inseminations per pregnancy with adjusted mean number of inseminations per pregnancy $( \pm \mathrm{SE}$ ) being $2.7 \pm 0.3$ for cows that had dystocia comparing to $2.0 \pm 0.1$ for cows that did not have dystocia. Presence or absence of VLD, and the presence or absence of a CL at 21 to 28 DIM were not associated with SCK.

\section{DISCUSSION}

To the best of our knowledge, this is the first study to show that SCK is associated with reduced intensity and duration of estrus activity. Itle et al. (2015) recently showed differences in standing behavior in the week before and on the day of calving between clinically ketotic and healthy cows, but an effect of SCK on estrus behavior was not addressed.

The prevalence of SCK across the 3 study herds was $17 \%$, it being at the mid to lower end of the range published in the literature (Oetzel, 2004; Macrae et al., 2012; McArt et al., 2012). Higher prevalences are routinely described in higher yielding dairy herds from North America; these animals may have a greater genetic potential for high milk production that can further exacerbate the degree of NEB and lead to SCK in early lactation. Some studies also use a lower blood BHB threshold to define SCK and sample cows in the first week postpartum; both of which could increase prevalence estimates (Macrae et al., 2012; McArt et al., 2012, 2013). A dairy cow has the potential to develop and resolve a case of SCK within $5 \mathrm{~d}$; therefore, when cows are only testing once during the period between 7 and 21 DIM, SCK cases have the potential to be underdiagnosed (McArt et al., 2012; Valergakis et al., 2012). Additionally, McArt et al. (2012) described the peak prevalence of SCK at 5 DIM, whereas in the study described here cows were sampled at 7 DIM or later, similar to other previously published studies (Berge and Vertenten, 2014; Vanholder et al., 2015). Ideally, we would have sampled the studied animals repeatedly during the first month after calving to decrease the chances of misclassification bias. Unfortunately, this was not possible due to time and budget limitations. However, several studies have followed a similar sampling regimen to show useful information regarding SCK risk factors or SCK effects on health and reproductive performance (Ospina et al., 2010; Suthar et al., 2013; Vanholder et al., 2015). It should also be stated that misclassification would bias our results toward the null hypothesis and, in that case, presented results could be considered conservative with the true differences being even greater than what we report here.

Cluster duration and mean peak activity increase in non-SCK cows were comparable throughout the study, and no differences were observed as lactation progressed. The mean duration of all increased activity clusters in non-SCK is comparable to the mean durations reported for cows monitored for estrus by visual observation of estrus behavior (Roelofs et al., 2005; Dobson et al., 2007) and estrus quantified by an accelerator system (Roelofs et al., 2005; Aungier et al., 2012; Valenza et al., 2012). The present study shows that SCK in early lactation has a profound effect on cluster duration and mean peak activity at first observed estrus and estrus leading to first insemination. This negative effect appears to diminish as cows progress through lactation. The cluster duration and mean peak activity increase in the estrus leading to pregnancy in SCK cows were comparable to that of non-SCK cows.

In addition, estrus cluster duration and mean peak activity increase in SCK cows did not seem to improve until over 100 DIM; the underlying mechanisms behind this are not fully clear. One interpretation is that for the cow to establish a pregnancy the physiology of the animal needs to progress to a state of positive energy balance whereby DMI is matching metabolic demands. Only then can the cow fully express behavioral estrus, evident as normal cluster duration and mean peak activity increase. It is likely this return in normal estrus behavior is directly related to estradiol production; a recent study by Morris et al. (2011) reported that lower circulating estradiol levels in lame cows were affecting behavioral expression of estrus. This may be further augmented by a reduction in IGF-1 and inadequate progesterone priming, without which the hypothalamus has diminished responsiveness to estradiol (Dobson et al., 2007); both of these conditions have been linked with NEB (Opsomer et al., 2000; Reist et al., 2000; Butler, 2003). It has also been shown that developing follicles are compromised when exposed to similar concentrations of glucose, nonesterified fatty acids, and BHB experienced by dairy cows in NEB with these follicles exhibiting reduced sensitivity to circulating $\mathrm{LH}$ leading to reduced estradiol production. If the compromised follicles reach dominance, ovulate, and are fertilized, they exhibit a reduced ability to cleave into a blastocyst and when coupled with poor CL formation and function, thus increasing the chance of embryo death (Leroy et al., 2006). Further research is required to fully understand which body systems are involved and how they interact to reduce physical activity at estrus in SCK cows. 
The current study confirms the negative effects of SCK on reproductive efficiency shown previously by other studies (Butler, 2003; Walsh et al., 2007; Ospina et al., 2010; McArt et al. 2012). Studies from North America use a large repertoire of ovulation synchronization protocols and typically only demonstrate the effects of SCK on reproductive parameters such as pregnancy risk in response to first insemination and the likelihood of removal from the herd in the first 30 DIM (Ospina et al., 2010; Chapinal et al., 2012; McArt et al., 2012). Few smaller scale studies (not utilizing synchronization protocols) have also demonstrated an association between SCK in early lactation and reduced reproductive efficiency (Reist et al., 2000; Cook et al., 2001; Walsh et al., 2007). In the present study, no synchronization protocols were used and the calving to first observed estrus and calving to first insemination intervals were both extended in cows suffering from SCK. This is comparable to the findings by Reist et al. (2000), where it was shown that cows in NEB and with increased blood concentrations of ketone bodies in early lactation had an increased calving to first service interval of $10 \mathrm{~d}$ compared with their nonaffected counterparts. Ospina et al. (2010) highlighted a reduced pregnancy risk in cows with SCK, and Walsh et al. (2007) established that SCK cows were 20 to $50 \%$ less likely to be pregnant at first insemination; these findings are in concurrence with our study's findings. We also report here that SCK cows take longer to establish a viable pregnancy than non-SCK cows. This is in agreement with Walsh et al. (2007) where an increased calving to pregnancy interval in SCK cows was reported. Previous studies have attributed this reduced reproductive performance to a delay in return to cyclicity due to reduced $\mathrm{GnRH}$ and LH pulsatility, which is essential for follicular development and ovulation (Butler, 2003). Interestingly, SCK in our study had a more profound effect on the interval from calving to pregnancy in multiparous cows, with SCK cows in their third or greater parity requiring 63 more days to establish a pregnancy compared with nonaffected third or greater parity cows.

\section{CONCLUSIONS}

The current study confirms the long-lasting effects of SCK on reproductive efficiency. Calving to first estrus, calving to first insemination and calving to pregnancy intervals were prolonged in SCK cows. Furthermore, it is indicated that physical activity around estrus can also be reduced by SCK in early lactation. The SCK cows exhibited a lower peak activity (measured as the number of standard deviations above mean activity) and shorter cluster duration in activity clusters associ- ated with first estrus and first insemination postpartum, compared with non-SCK cows.

\section{ACKNOWLEDGMENTS}

This work was carried out by A. J. R. in partial fulfilment of the requirements for the Diploma in Bovine Reproduction, University of Liverpool. A. J. R. thanks the farmers involved in data collection, the directors of Farm Gate Veterinary Services for their assistance, and Fabdec (Ellesmere, UK) and Elanco (Basingstoke, UK) for providing technical support.

\section{REFERENCES}

Andersson, L. 1988. Subclinical ketosis in dairy cows. Vet. Clin. North Am. Food Anim. Pract. 4:233-251.

Aungier, S. P. M., J. F. Roche, M. Sheehy, and M. A. Crowe. 2012. Effects of management and health on the use of activity monitoring for estrus detection in dairy cows. J. Dairy Sci. 95:2452-2466.

Berge, A. C., and G. Vertenten. 2014. A field study to determine the prevalence, dairy herd management systems, and fresh cow clinical conditions associated with ketosis in western European dairy herds. J. Dairy Sci. 97:2145-2154.

Butler, W. R. 2003. Energy balance relationships with follicular development, ovulation and fertility in postpartum dairy cows. Livest. Prod. Sci. 83:211-218.

Chapinal, N., S. J. LeBlanc, M. E. Carson, K. E. Leslie, S. Godden, M. Capel, and J. E. P. Santos. 2012. Herd-level association of serum metabolites in the transition period with disease, milk production, and early lactation reproductive performance. J. Dairy Sci. 95:5676-5682.

Cook, N. B., W. R. Ward, and H. Dobson. 2001. Concentrations of ketones in milk in early lactation, and reproductive performance of dairy cows. Vet. Rec. 148:769-772.

Dechow, C. D., G. W. Rogers, L. Klei, and T. J. Lawlor. 2003. Heritabilities and correlations among body condition score, dairy form and selected linear type traits. J. Dairy Sci. 86:2236-2242.

Dobson, H., R. F. Smith, M. D. Royal, C. H. Knight, and I. M. Sheldon. 2007. The high-producing dairy cow and its reproductive performance. Reprod. Domest. Anim. 42:17-23.

Drackley, J. K. 1999. Biology of dairy cows during the transition period: The final frontier? J. Dairy Sci. 82:2259-2273.

Duffield, T. F., D. F. Kelton, K. E. Leslie, K. D. Lissemore, and J. H. Lumsden. 1997. Use of test day milk fat and milk protein to detect subclinical ketosis in dairy cattle in Ontario. Can. Vet. J. 38:713-718.

Duffield, T. F., K. D. Lissemore, B. W. McBride, and K. E. Leslie. 2009. Impact of hyperketonemia in early lactation dairy cows on health and production. J. Dairy Sci. 92:571-580.

Duffield, T. F., D. Sandals, K. E. Leslie, K. Lissemore, B. W. McBride, J. H. Lumsden, P. Dick, and R. Bagg. 1998. Efficacy of monensin for the prevention of subclinical ketosis in lactating dairy cows. J. Dairy Sci. 81:2866-2873.

Enjalbert, F., M. C. Nicot, C. Bayourthe, and R. Moncoulon. 2001. Ketone bodies in milk and blood of dairy cows: Relationship between concentrations and utilization for detection of subclinical ketosis. J. Dairy Sci. 84:583-589.

Firk, R., E. Stamer, W. Junge, and J. Krieter. 2002. Automation of estrus detection in dairy cows: A review. Livest. Prod. Sci. 75:219232.

Fricke, P. M., J. O. Giordano, A. Valenza, G. Lopes Jr., M. C. Amundson, and P. D. Carvalho. 2014. Reproductive performance of lactating dairy cows managed for first service using timed artificial insemination with or without detection of estrus using an activitymonitoring system. J. Dairy Sci. 97:2771-2781. 
Geishauser, T., K. Leslie, D. Kelton, and T. Duffield. 2001. Monitoring for subclinical ketosis in dairy herds. Compend. Contin. Educ. Pract. Vet. 23:65-71.

Herdt, T. H. 2000. Ruminant adaptation to negative energy balance. Influences on the etiology of ketosis and fatty liver. Vet. Clin. North Am. Food Anim. Pract. 16:215-230.

Holman, A., J. Thompson, J. E. Routly, D. N. Cameron, D. N. Jones, D. Grove-White, R. F. Smith, and H. Dobson. 2011. Comparison in estrus detection methods in dairy cattle. Vet. Rec. 169:47.

Itle, A. J., J. M. Huzzey, D. M. Weary, and M. A. G. von Keyserlingk. 2015. Clinical ketosis and standing behavior in transition cows. J. Dairy Sci. 98:128-134.

Iwersen, M., U. Falkenberg, R. Voigtsberger, D. Forderung, and W. Heuwieser. 2009. Evaluation of an electronic cow side test to detect subclinical ketosis in dairy cows. J. Dairy Sci. 92:2618-2624.

Leroy, J. L. M. R., T. Vanholder, G. Opsomer, A. Van Soom, and A. de Kruif. 2006. The in vitro development of bovine oocytes after maturation in glucose and B-hydroxybutyrate concentrations associated with negative energy balance in dairy cows. Reprod. Domest. Anim. 41:119-123.

Lopez, H., L. D. Satter, and M. C. Wiltbank. 2004. Relationship between level of milk production and estrous behavior of lactating dairy cows. Anim. Reprod. Sci. 81:209-223.

Lucy, M. C. 2000. Regulation of ovarian follicular growth by somatotropin and insulin-like growth factors in cattle. J. Dairy Sci. 83:1635-1647.

Lucy, M. C. 2001. Reproductive loss in high-producing dairy cattle: Where will it end? J. Dairy Sci. 84:1277-1293.

Macrae, A. I., E. Burrough, and J. Forrest. 2012. Assessment of nutrition in dairy herds: Use of metabolic profiles. Cattle Pract. 20:120-127.

McArt, J. A. A., D. V. Nydam, and G. R. Oetzel. 2012. Epidemiology of subclinical ketosis in early lactation dairy cattle. J. Dairy Sci. 95:5056-5066.

McArt, J. A. A., D. V. Nydam, G. R. Oetzel, T. R. Overton, and P. A. Ospina. 2013. Elevated non-esterified fatty acids and $\beta$-hydroxybutyrate and their association with transition dairy cow performance. Vet. J. 198:560-570.

Morris, M. J., K. Kaneko, S. L. Walker, D. N. Jones, J. E. Routly, R. F. Smith, and H. Dobson. 2011. Influence of lameness on follicular growth, ovulation, reproductive hormone concentrations and estrus behavior in dairy cows. Theriogenology 76:658-668.

Nebel, R. L., M. G. Dransfield, S. M. Jobst, and J. H. Bame. 2000. Automated electronic systems for the detection of estrus and timing of AI in cattle. Anim. Reprod. Sci. 60-61:713-723.

Neves, R. C., K. E. Leslie, J. S. Walton, and S. J. LeBlanc. 2012. Reproductive performance with an automated activity monitor- ing system versus a synchronized breeding program. J. Dairy Sci. 95:5683-5693.

Oetzel, G. R. 2004. Monitoring and testing dairy herds for metabolic disease. Vet. Clin. North Am. Food Anim. Pract. 20:651-674.

Opsomer, G., Y. T. Grohn, J. Hertl, M. Coryn, H. Deluyker, and A. de Kruif. 2000. Risk factors for postpartum ovarian dysfunction in high producing dairy cows in Belgium: A field study. Theriogenology 53:841-857.

Ospina, P. A., D. V. Nydam, T. Stokol, and T. R. Overton. 2010. Associations of elevated nonesterified fatty acids and beta-hydroxybutyrate concentrations with early lactation reproductive performance and milk production in transition dairy cattle in the northeastern United States. J. Dairy Sci. 93:1596-1603.

Reist, M., I. A. Koller, A. Busato, U. Ktipfer, and J. W. Blum. 2000. First ovulation and ketone body status in the early postpartum period of dairy cows. Theriogenology 54:685-701.

Roelofs, J. B., F. J. C. M. Van Eerdenburgh, N. M. Soede, and B. Kemp. 2005. Pedometer readings for estrus detection and as predictor for time of ovulation in dairy cattle. Theriogenology 64:1690-1703.

Sheldon, I. M., G. S. Lewis, S. LeBlanc, and R. O. Gilbert. 2006 Defining postpartum uterine disease in cattle. Theriogenology 65:1516-1530.

Suthar, V. S., J. Canelas-Raposo, A. Deniz, and W. Heiwieser. 2013. Prevalence of subclinical ketosis and relationships with postpartum diseases in European dairy cows. J. Dairy Sci. 96:2925-2938.

Valenza, A., J. O. Giordano Jr., G. Lopes, L. Vincenti, M. C. Amundson, and P. M. Fricke. 2012. Assessment of an accelerometer system for detection of estrus and treatment with gonadotrophinreleasing hormone at the time of insemination in lactating dairy cows. J. Dairy Sci. 95:7115-7127.

Valergakis, G. E., G. Oikonomou, G. Arsenos, and G. Banos. 2012. Epidemiologic characteristics of subclinical ketosis in dairy cows. Page 22 in Proc. XXVII World Buiatrics Congr., Lisbon.

van Arendonk, J. A. M., G. J. Nieuwhof, H. Vos, and S. Korver. 1991. Genetic aspects of feed intake and efficiency in lactating dairy heifers. Livest. Prod. Sci. 29:263-275.

Vanholder, T., J. Papen, R. Bemers, G. Verenten, and A. C. B. Berge. 2015. Risk factors for subclinical and clinical ketosis and association with production parameters in dairy cows in the Netherlands. J. Dairy Sci. 98:880-888.

Walsh, R. B., J. S. Walton, D. F. Kelton, S. J. LeBlanc, K. E. Leslie, and T. F. Duffield. 2007. The Effect of subclinical ketosis in early lactation on reproductive performance of postpartum dairy cows. J. Dairy Sci. 90:2788-2796. 